\title{
SCREENING OF MUCOR SPP. FOR THE PRODUCTION OF AMYLASE, LIPASE, POLYGALACTURONASE AND PROTEASE
}

\author{
Maria Helena Alves ${ }^{1,2,3 *}$; Galba M. Campos-Takaki³; Ana Lúcia Figueiredo Porto ${ }^{3,4}$; Adauto Ivo Milanez \\ 'Centro de Ciências Agrárias e Biológicas, Coordenação de Biologia, Universidade Estadual Vale do Acaraú, Sobral, CE, Brasil; \\ ${ }^{2}$ Laboratório de Imunopatologia Keizo Asami, Universidade Federal do Pernambuco, Recife, PE, Brasil; ${ }^{3}$ Departamento de \\ Química, Núcleo de Pesquisas em Ciências Ambientais, Universidade Católica de Pernambuco, Recife, PE, Brasil; \\ ${ }^{4}$ Departamento de Morfologia e Fisiologia Animal, Universidade Federal Rural de Pernambuco, PE, Brasil; 5 Instituto de \\ Botânica, Secretaria do Meio Ambiente, São Paulo, SP, Brasil.
}

Submitted: October 03, 2002; Returned to authors for corrections February 20, 2002; Approved: December 05, 2002.

\begin{abstract}
Fungi are well known by their ability to excrete enzymes into the environment. Among them, representatives of Mucor Fresen. have important biotechnological potential and some of them produce industrial enzymes. This work studied amylase, lipase, polygalacturonase and protease production by fifty-six isolates of Mucor belonging to 11 different taxa, selected from herbivores dung using solid media. The results showed that the majority of the isolates presented several enzymatic activities with predominance of polygalacturonase $(96 \%)$, followed by amylase $(84 \%)$, protease ( $82 \%)$ and lipase $(66 \%)$.
\end{abstract}

Key words: Fungal enzymes, Mucor, amylase, lipase, polygalacturonase, protease, herbivorous dung

The enzymes are essential proteins for the metabolic system of all living organisms and have an important role in the degradation of organic matter, in host infection and food spoilage. In the metabolic pathways, they act in organized sequences of catabolic and anabolic routes (12). Enzymes may also act in the control of biochemical processes in the living cells. They may be isolated from animals, plants and microorganisms. The last ones are considered good sources of industrial enzymes for the great diversity of enzymes that have been found (13). The enzymes are used in large scale in the textile (amylase, cellulase, oxidoreductase); detergents (protease, lipase, cellulase, oxidoreductase); food (pectinase, protease, cellulase, oxidoreductase); paper (xylanase, oxidoreductase and lipase) and leather (protease, lipase) industries (14).

Extracellular enzymes may be produced in liquid or solid media. The use of solid media permits a fast screening of large populations of fungi, allowing the detection of specific enzymes $(3,8,10,17,19,20)$ and helping in the chemotaxonomical differentiation of many microorganisms (10). The production of enzymes by microorganisms assures a potential and unlimited supply and also makes it possible the genesis of new enzymatic systems that cannot be obtained from plant or animal sources $(2,13)$.

The species of the genus Mucor constitute a group of microorganisms responsible for the production of several enzymes such as amylases, lipases, pectinases and proteases (5,16,20). Mucor hiemalis, M. racemosus (15), M. bacilliformis (7) and M. miehei (6) present protease activity of commercial value and $M$. miehei is the most studied specie concerning the production of lipase (14).

The objective of this work was to detect the presence of the aforementioned enzymes by taxa of Mucor isolated from herbivores dung, using solid culture media.

The 11 taxa of Mucor isolated from dung of herbivores animals, from two locations in Recife, PE (1), are shown in the Table 1 . These microorganisms have been preserved by the Castelani method (4) in culture collections of the following institutions: Catholic University of Pernambuco (UCP-

\footnotetext{
* Corresponding author. Mailing address: Centro de Ciências Agrárias e Biológicas, Coordenação de Biologia, Universidade Estadual Vale do AcaraúUVA. Av. da Universidade, 850, Campus da Betânia, Sobral, CE, Brasil. 62011-970. E-mail: mahelenalves@bol.com.br
} 
Table 1. Taxa and identification number of the isolates in the Culture Collections of UCP, URM and SPC, indicating the herbivores animal origin.

\begin{tabular}{|c|c|c|c|c|c|}
\hline \multirow[t]{2}{*}{ TAXA } & \multicolumn{3}{|c|}{ Culture Collection } & \multirow[t]{2}{*}{ Dung/Animal } & \multirow[t]{2}{*}{ Origin/Animal } \\
\hline & $\mathrm{UCP}$ & URM & SPC & & \\
\hline \multirow{4}{*}{ Mucor circinelloides f. circinelloides } & 6 & 4136 & 1768 & Bos indicus Linnaeus & $\mathrm{ZOO}$ \\
\hline & 36 & 4140 & & Bison bonasus H. Smith & PDI \\
\hline & 37 & & & Bison bonasus $\mathrm{H}$. Smith & PDI \\
\hline & 53 & & & Bison bonasus H. Smith & PDI \\
\hline \multirow[t]{9}{*}{ M. circinelloides f. griseo-cyanus } & 1 & 4183 & 1769 & Bison bonasus H. Smith & PDI \\
\hline & 20 & 4182 & & Mazama gouazoubira Fischer & PDI \\
\hline & 42 & & & Mazama gouazoubira Fischer & PDI \\
\hline & 47 & 4192 & & Ovis aries Linnaeus & $\mathrm{ZOO}$ \\
\hline & 46 & & & Bison bonasus H. Smith & PDI \\
\hline & 54 & 4184 & & Capra hircus Linnaeus & $\mathrm{ZOO}$ \\
\hline & 55 & 4185 & & Oryctolagus cuniculus Lilljeborg & $\mathrm{ZOO}$ \\
\hline & 57 & 4160 & & Taurotragus oryx Wagner & PDI \\
\hline & 58 & & & Ovis aries Linnaeus & $\mathrm{ZOO}$ \\
\hline \multirow[t]{4}{*}{ M. circinelloides $\mathrm{f}$. janssenii } & 8 & 4139 & & Taurotragus oryx Wagner & PDI \\
\hline & 9 & 4148 & & Mazama gouazoubira Fischer & PDI \\
\hline & 10 & & & Oryctolagus cuniculus Lilljeborg & $\mathrm{ZOO}$ \\
\hline & 19 & 4141 & 1770 & Oryctolagus cuniculus Lilljeborg & $\mathrm{ZOO}$ \\
\hline M. circinelloides f. lusitanicus & 51 & 4137 & 1771 & Mazama gouazoubira Fischer & PDI \\
\hline \multirow{4}{*}{ M. genevensis } & 7 & 4188 & 1772 & Dasyprocta fuliginosa Wagler & PDI \\
\hline & 15 & & & Dasyprocta fuliginosa Wagler & PDI \\
\hline & 23 & 4187 & & Ovis aries Linnaeus & $\mathrm{ZOO}$ \\
\hline & 24 & & & Ovis aries Linnaeus & $\mathrm{ZOO}$ \\
\hline \multirow[t]{8}{*}{ M. hiemalis f. hiemalis } & 12 & & & Equus caballus Linnaeus & $\mathrm{ZOO}$ \\
\hline & 13 & & & Capra hircus Linnaeus & $\mathrm{ZOO}$ \\
\hline & 14 & & & Oryctolagus cuniculus Lilljeborg & $\mathrm{ZOO}$ \\
\hline & 18 & 4190 & & Mazama gouazoubira Fischer & PDI \\
\hline & 28 & 4193 & 1773 & Dasyprocta fuliginosa Wagler & PDI \\
\hline & 30 & & & Mazama gouazoubira Fischer & PDI \\
\hline & 31 & & & Mazama gouazoubira Fischer & PDI \\
\hline & 52 & & & Bison bonasus H. Smith & PDI \\
\hline \multirow[t]{9}{*}{ M. hiemalis f. luteus } & 5 & 4186 & 1774 & Ovis aries Linnaeus & $\mathrm{ZOO}$ \\
\hline & 11 & 4191 & & Dasyprocta fuliginosa Wagler & PDI \\
\hline & 17 & & & Dasyprocta fuliginosa Wagler & PDI \\
\hline & 2 & 4142 & & Oryctolagus cuniculus Lilljeborg & $\mathrm{ZOO}$ \\
\hline & 35 & & & Ovis aries Linnaeus & $\mathrm{ZOO}$ \\
\hline & 44 & 4144 & & Equus caballus Linnaeus & $\mathrm{ZOO}$ \\
\hline & 45 & & & Ovis aries Linnaeus & $\mathrm{ZOO}$ \\
\hline & 48 & 4147 & & Capra hircus Linnaeus & $\mathrm{ZOO}$ \\
\hline & 50 & & & Ovis aries Linnaeus & $\mathrm{ZOO}$ \\
\hline M. piriformis & 41 & 4145 & 1775 & Equus caballus Linnaeus & $\mathrm{ZOO}$ \\
\hline \multirow[t]{14}{*}{ M. racemosus f. chibinensis } & 2 & 4149 & 1777 & Capra hircus Linnaeus & $\mathrm{ZOO}$ \\
\hline & 3 & & & Dasyprocta fuliginosa Wagler & PDI \\
\hline & 4 & & & Dasyprocta fuliginosa Wagler & PDI \\
\hline & 16 & & & Dasyprocta fuliginosa Wagler & PDI \\
\hline & 21 & & & Dasyprocta fuliginosa Wagler & PDI \\
\hline & 26 & 4135 & & Bison bonasus $\mathrm{H}$. Smith & PDI \\
\hline & 27 & & & Dasyprocta fuliginosa Wagler & PDI \\
\hline & 33 & & & Dasyprocta fuliginosa Wagler & PDI \\
\hline & 34 & & & Dasyprocta fuliginosa Wagler & PDI \\
\hline & 39 & & & Oryctolagus cuniculus Lilljeborg & $\mathrm{ZOO}$ \\
\hline & 40 & & & Oryctolagus cuniculus Lilljeborg & $\mathrm{ZOO}$ \\
\hline & 43 & 4143 & & Dasyprocta fuliginosa Wagler & $\mathrm{ZOO}$ \\
\hline & 49 & & & Dasyprocta fuliginosa Wagler & PDI \\
\hline & 56 & & & Dasyprocta fuliginosa Wagler & PDI \\
\hline M. subtilissimus & 29 & 4133 & 1778 & Equus caballus Linnaeus & $\mathrm{ZOO}$ \\
\hline M. variosporus & 25 & 4219 & 1779 & Mazama gouazoubira Fischer & PDI \\
\hline
\end{tabular}

PDI=Parque Dois Irmãos, Recife, Pernambuco; Zoo=Department of Zootecny of the University Federal Rural of Pernambuco. Font: (1) modified. 
UNICAP), Recife/PE; Section of Mycology and Lichnology from the Institute of Botany (SPC), São Paulo/SP and the Department of Micology from Federal University of Pernambuco (URMUFPE), Recife, PE.

The isolates were reactivated in Petri dishes containing Synthetic Mucor Agar (SMA) (Hesseltine and Anderson (11) and/or Potato Dextrose Agar (PDA) and submitted to monosporic cultivation according to the methodology proposed by Gams et al. (9) in order to obtain pure cultures and to diminish variability at the morpho-physiologic, biochemical and genetic levels when submitted to successive cultivations.

A suspension of spores was prepared from the monosporic colonies. The mycelium was washed with sterilized distilled water with the aid of glass beads, and the suspension aseptically transferred to a test tube. An aliquot of this suspension was removed for counting in a Newbauer Camera, under optical microscope, and diluted whenever necessary to obtain $10^{6}$ spores $/ \mathrm{mL}$.

For detection of enzymes, the methodology used was the one proposed by Hankin and Anagnostakis (10), modified with the substitution of the "hexadecyltrimethylammonium bromide" by hydrochloric acid $(\mathrm{HCl}) 5 \mathrm{~N}$. To verify the activity of the enzymes amylases, lipases, pectinases (polygalacturonases) and proteases, soluble starch (Merck), Tween 20 (Merck), citric pectin (INLAB) and jelly (Difco) were used as substrate, respectively. In a Petri dish containing $15 \mathrm{~mL}$ of the relevant substratum, a disk of $5 \mathrm{~mm}$ of diameter was removed from the central part of the medium, and the hole filled in with $50 \mu \mathrm{L}$ of $10^{6}$ spores $/ \mathrm{mL}$ suspension, and incubated at $28^{\circ} \mathrm{C}$. All the tests were performed in triplicate.

The level of enzyme production was evaluated by the halo diameter, measured in centimeters, in the reverse of the Petri dish. The halo produced by amylase, lipase and polygalacturonase activity was measured within 72 hours and for protease within 96 hours.

Data of the halo diameter averages were analyzed according to Fisher's protected LSD test $(\mathrm{P}<0.05)$.

According to data presented in Table 2, higher amylases activities (halo $\geq 8 \mathrm{~cm}$ ) were presented by isolates 37 and $53(M$. circinelloides f. circinelloides), 47 (M. circinelloides $\mathrm{f}$. griseocyanus), 30 and 31 (M. hiemalis f. hiemalis), 48 (M. hiemalis $\mathrm{f}$. luteus), 21 and 43 (M. racemosus f. chibinensis) and 25 (M. variosporus), while the isolates of $M$. circinelloides f. lusitanicus and $M$. piriformis were negative for this activity. Isolates $M$. circinelloides f. circinelloides, M. circinelloides f. griseocyanus, M. hiemalis f. hiemalis, M. racemosus f. chibinensis and $M$. variosporus were also good producers amylase (halo with average $\geq 7 \mathrm{~cm}$ ) Fig. 1A.

Thompson and Eribo (17) and Petruccioli and Federici (16) detected amylase activity in species of Mucor. However, the degradation halo presented by these authors (1-2 $\mathrm{mm}$ and up to $2 \mathrm{~mm}$, respectively) were lower than the ones verified in this work. For M. piriformis, Thompson and Eribo (17) mentioned the presence of amylase activity, which was not observed in the isolate used in our experiment. On the other hand, amylases activity was observed in the isolate of $M$. genevensis, while Petruciolli and Federici (16) did not detect this activity in the isolate used in their work (Table 2).

All taxa studied showed lipases activity with predominance of M. genevensis, M. circinelloides f. griseo-cyanus and $M$. circinelloides $\mathrm{f}$. janssenii species (halo with average $>6 \mathrm{~cm}$ ). The isolates numbered 1, 46 and 47 (M. circinelloides f. griseocyanus), 10 (M. circinelloides f. janssenii) and 23 (M. variosporus) were the ones that presented the highest lipases activity (halo $\geq$ $7 \mathrm{~cm}$ ) (Table 2), while for the averages presented $M$. circinelloides f. lusitanicus showed the lowest lipases activities (Fig. 1B).

These results are in accordance with the data presented by Vágvölgyi et al. (18) that detected lipase activity in 27 isolates of 10 different species of Mucor. They do not agree with the results obtained by Thompson and Eribo (17) that did not detect lipase activity in M. hiemalis, M. mucedo, M. piriformis and $M$. racemosus f. racemosus.

In Table 2 it is shown that a large number of isolates (54) presented polygalacturonase activity, mainly the ones numbered 5, 32 and 44 (M. hiemalis f. luteus), 15 and 24 (M. genevensis), 34, 39 and 56 (M. racemosus f. chibinensis) and 53 (M. circinelloides f. circinelloides) with halo $\geq 8 \mathrm{~cm}$. Except for M. subtilissimus, all taxa presented polygalacturonase activity. M. circinelloides $\mathrm{f}$. lusitanicus, followed by M. hiemalis f. luteus, M. piriformis and M. genevensis (average end of halo $>7 \mathrm{~cm}$ ) showed the bests halo average for this enzyme (Fig. 1C). These data were similar to the ones presented by Thompson and Eribo (17) that observed polygalacturonase activity in three of the four species of Mucor studied. In this work, among the 56 isolates studied, only two isolates did not produced polygacturonase. These results agree with Petruccioli and Federici (16) that detected polygalacturonase in $M$. genevensis, $M$. racemosus and $M$. ramannianus, but the degradation halo (1-9.5 $\mathrm{mm}$ and 2-8 $\mathrm{mm})$ produced by $M$. genevensis and $M$. racemosus, respectively, were smaller than the ones obtained in this study.

In Table 2 it can be observed that the majority of the isolates presented protease activity and that the isolates numbered 3,4 , 26, 33 and 40 (M. racemosus $\mathrm{f}$. chibinensis), 6 (M. circinelloides f. circinelloides), 7 and 23 (M. genevensis), 8 (M. circinelloides f. janssenii), 11 and 32 (M. hiemalis f. luteus), 18 (M. hiemalis f. hiemalis) and 57, 58 (M. circinelloides f. griseo-cyanus) were the ones that demonstrated the biggest halo $(\geq 5.5 \mathrm{~cm})$. It may be observed that the majority showed proteases activity without significant differences among them (Fig. 1D).

The results obtained with the proteases activity agree with the data observed by Thompson and Eribo (17) that obtained this enzymatic activity in four species of Mucor. Petruccioli and Federici (16) also detected proteases activity in M. racemosus and M. ramannianus. Hankin and Anagnostakis (10) observed 
M.H. Alves et al.

Table 2. Averages diameters halo $(\mathrm{cm})$ for the enzymatic activities in taxa of Mucor and respective isolates.

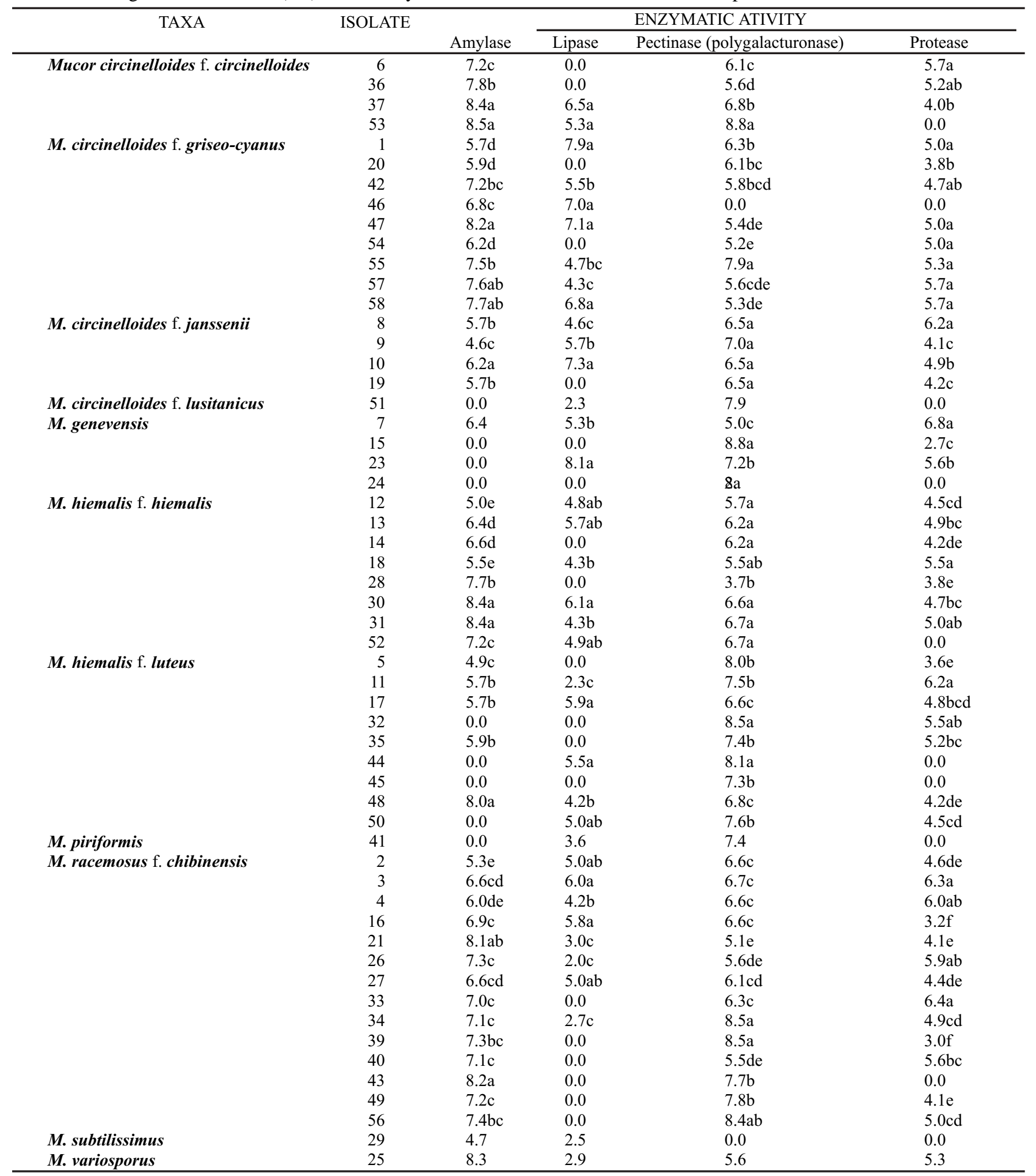

Averages equal to zero were not included in the statistical analysis. Numbers followed by the same letter among the isolates group of each species were not significantly different according to Fischer's protected LSD test. 

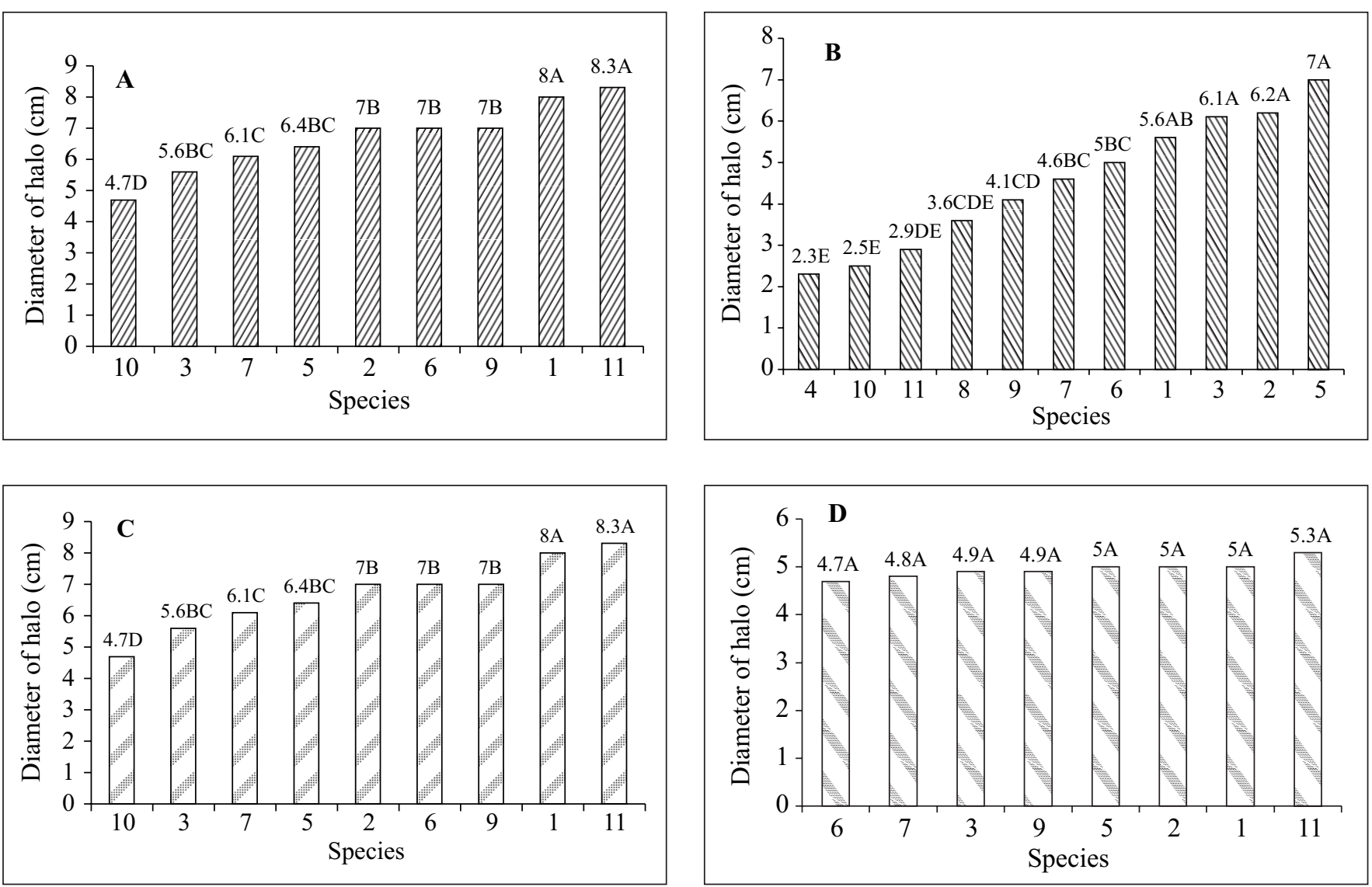

Figure 1. Average diameter of halo (cm) for the activities of amylase (A), lipase (B), polygalacturonase (C) and protease (D) in species of Mucor: 1 - M. circinelloides f. circinelloides; 2 - M. circinelloides f. griseo-cyanus; 3 - M. circinelloides f. janssenii; 4 - M. circinelloides f. lusitanicus; 5 - M. genevensis; 6 - M. hiemalis f. hiemalis; 7 - M. hiemalis f. luteus; 8 - M. piriformis; 9 - M. racemosus f. chibinensis; 10 - M. subtilissimus and 11 - M. variosporus. Numbers followed by the same letter are not significantly different according to Fischer's protected LSD test.

protease activity in Mucor sp, although the degradation halo diameters mentioned by these authors were smaller than the ones obtained in this work.

The results show that all Mucor isolates possessed a high potential for enzyme production, especially lipase, which was present in the majority of the taxa studied. It was observed that enzymatic activity does not establish true standards for separation of the taxa at a specific level since it varied in different isolates belonging to the same taxon.

\section{ACKNOWLEDGMENTS}

The authors are grateful to CNPq for financial support, and Dr. Everardo Sampaio, (Departamento de Energia Nuclear - DEN/ UFPE); Dra. Kaoru Okada (Departamento de Biologia/UNICAP) and Inês Helena Ferreira Pessoa (UNICAP/PIBIC/FACEPE) for their collaboration.

\section{RESUMO}

\section{Screening de Mucor spp. para produção de amilase, lipase, poligalacturonase e protease}

Os fungos apresentam a capacidade de produzir e secretar enzimas para o meio ambiente. Entre esses, representantes de Mucor Fresen constituem um grupo de microrganismos com importante potencial biotecnológico, sendo responsáveis pela produção de várias enzimas usadas em processos industriais. Foi observado que 56 isolados do gênero Mucor, totalizando 11 táxons, obtidos de fezes de herbívoros são capazes de produzir amilase, lipase, polygalacturonase e protease em meios sólidos. Os resultados demonstraram que $96 \%$ dos isolados produziram poligalacturonase, $(84 \%)$ amilase, $(82 \%)$ protease e $(66 \%)$ lipase.

Palavras-chave: Enzimas fúngicas, Mucor, amilase, lipase, poligalacturonase, protease, fezes de herbívoros. 


\section{REFERENCES}

1. Alves, M.H.; Trufem, S.F.B.; Milanez, A.I. Táxons de Mucor Fresen. (Zygomycota) em fezes de herbívoros, Recife, PE, Brasil. Rev. Brasil. Bot., 25(2): 147-160, 2002.

2. Aunstrup, K. Proteinases in Economic Microbiology: Microbial Enzymes and Bioconversions (A.H. Rose ed.), 5: 49-114. Academic Press, New York, 1980

3. Brühlmann, F.; Kim, K.S.; Zimmerman, W.; Fiechter, A. Pectinolytic enzymes from Actnomycete for the degumming of ramie bast fibers. Appl. Environm. Microbiol., 60: 2107-2112, 1994.

4. Castellani, A. Viability of mould culture of fungi in distilled water. $J$. Trop. Med. Hyg., 42: 225, 1939.

5. Domsch, K.H.; Gams, W.; Anderson, T.H. Compendium of soil fungi. IHW-Verlag, Alemanha, 1995, 859p.

6. Escobar, J.; Barnett, S.M. Effect of agitation speed on the synthesis of Mucor miehei acid protease. Enz. Microb. Technol., 15: 10091013, 1993.

7. Fernández-Labore, H.M.; Fraile, E.R.; Cascone, O. Acid protease recovery from a solid-state fermentation system. J. Biotechnol., 62: 83-93, 1998

8. Federici, F. Extracellular enzimatic activities in Aureobasidium pullulans. Mycology, 74: 738-743, 1982.

9. Gams, W.A.J.; Samson, R.A.; Stalpers, J.A. CBS course of mycology. England: CVSB. Academy of Sciences and Letters, 1975, 104p.

10. Hankin, L.; Anagnostakis, S.L. The use of solid media for detection of enzyme production by fungi. Mycology, 67: 597-606, 1975.
11. Hesseltine, C.W.; Anderson, R.F. Microbiological production of carotenoids. I. Zygospore and carotene produced by intraspecific and interspecific clones of Choanephoraceae in liquid media. Mycol., 49: 449-452, 1957

12. Lehninger, A.L. Princípios de Bioquímica. São Paulo. Sarvier, 1988, $725 \mathrm{p}$.

13. Lima, V.A.; Aquarone, E.; Barzani, V. Biotecnologia - tecnologia das fermentações. Ed. Edgard Blücher Ltda, São Paulo. 1986, Vol. 1, $285 \mathrm{p}$.

14. Nielsen, R.I.; OxenbØ11, K. Enzymes from fungi: their technology and uses. Mycologist, 12: 69-71, 1998.

15. Perraud, R.; Laboret, F. Optimization of metyl propionate production catalised by Mucor miehei lipase. Appl. Microb. Biotechnol., 44: 321-326, 1995

16. Petruccioli, M.; Federici, R.G. A note on the production of extracellular hydrolytic enzymes by yeast-like fungi and related microorgnisms. Ann. Microbiol. Enzimol., 42: 81-86, 1992.

17. Thompson, D.P.; Eribo, B.E. Extracellular enzyme production by Rhizopus and Mucor species on solid media. Can. J. Microbiol., 30 126-128, 1994

18. Vágvölgyi, C.; Papp, T.; Palágyi, Z.; Michailides, T.J. Isozyme variation among isolates of Mucor piriformis. Mycology, 88: 602-607, 1996b.

19. Weber, R.W.S.; Pitt, D.; Webster, J. Teaching techniques for mycology: 3. Amylase secretion by Aspergillus oryzae. Mycologist, 12: 8-9, 1998.

20. Zare-Maivan, H.; Shearer, C.A. Extracellular enzyme production and cell wall degradation by freshwater lignicolous fungi. Mycology, 80: $365-375,1988$ 